\title{
Tissue schistosomiasis in accra ghana: a retrospective histopathologic review at the korle-bu teaching hospital (2004-2011)
}

\author{
Edmund Muonir Der ${ }^{1,3^{*}}$, Solomon E. Quayson ${ }^{1}$, James E. Mensah ${ }^{2}$ and Yao Tettey ${ }^{1}$ \\ *Correspondence: maadelle@yahoo.com

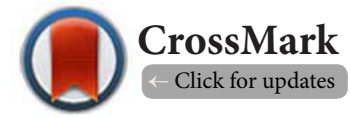 \\ 'Department of Pathology, College of Health Sciences, Korle-Bu, Accra, Ghana. \\ ${ }^{2}$ Department of Surgery, University of Ghana Medical School, Accra, Ghana. \\ ${ }^{3}$ Department of Pathology, University for Development Studies, Tamale, Ghana.
}

\begin{abstract}
Background: Schistosomiasis is a neglected tropical parasitic infection. The aim of this study was to determine how frequently different structures within the pelvis and perineum were infected with schistosomiasis and its association with cancer, in surgical pathology specimens in a tertiary hospital in Ghana.

Materials and methods: We reviewed all surgical pathological cases from January 2004 to December 2011 for tissue schistosomiasis. Data were analyzed using SPSS software version 18 (Chicago IL). Identification of the type of schistosoma specie was based on the external features of the ova.

Results: A total of 42,340 surgical specimens were reviewed of which 151(0.4\%) showed schistosoma ova, commonly S. haematobium (98.7\%). Mean age of the patients was 36.3 years ( $\mathrm{SD}=16.9)$. Organs involved were; appendix (41.7\%), urinary bladder (36.4\%), colon (4.6\%), ureters (4.0\%), fallopian tube (3.3\%), cervix (2.65) and prostate (2.0\%). Appendiceal schistosomiasis was the most common in males $48(49.5 \%)$, while urinary bladder schistosomiasis was most common in females (40.7\%). A total of 31(20.5\%) cases were associated with cancer, mean age $52.1(\mathrm{SD}=14.6)$ years and commonly in the urinary bladder $(93.6 \%)$. Majority of the cancers were Squamous Cell Carcinoma (71.0\%), with 25.8\% transitional cell carcinoma and $3.2 \%$ adenocarcinoma of the prostate.

Conclusion: We found tissue schistosomiasis prevalence rate of $0.4 \%$ among surgical pathological specimens. The commonest species identified was $S$. haematobium. The appendix was the organ most commonly involved. About $20.5 \%$ of all cases were associated with cancer and occurred in a relatively older age group of the study population.
\end{abstract}

Keywords: Pelvis tissues, schistosomiasis, cancer, ghana

\section{Introduction}

Schistosomiasis is a chronic parasitic infection caused by several species of trematode of the genus Schistosoma with fresh snails as the intermediate hosts. It is the third most devastating tropical disease in the world, being a major source of morbidity and mortality in developing countries in Africa, South America, the Caribbean, the Middle East, and Asia, affecting approximately 250 million people [1-3]. Infection of the urogenital, gastrointestinal organs and the perineal structures by schistosome parasite is well recognized. Any of the schistosomes can infect these organs, however the commonest is the $S$. haematobium $[5,6]$. The bladder is usually the seat of the infection. Other organs affected are vulva, vagina, cervix, fallopian tubes, ovaries, uterus, ureters, appendix, colon and prostate [7]. How frequently the different pelvic structures are affected is not clearly defined in the literature. Gelfand in his study using autopsy material found the following in descending order: urinary bladder, rectum, vagina, cervix, and fallopian tubes [7]. The close relationship between the vessels of the pelvic organs and the urinary bladder enables the parasite 
Der et al. Pathology Discovery 2015,

to easily change location to virtually any organ in the pelvis. Symptoms depend on the anatomical location of the ova.

The aim of this study was to determine how frequently different structures within the pelvis and perineum were infected with schistosomiasis and its association with cancer, as seen in surgical pathology specimens in a tertiary hospital in Ghana.

\section{Materials and methods}

We reviewed all histologic reports from 2004 to 2011 for cases of tissue schistosomiasis in the Department of Pathology, Korle-Bu Teaching Hospital. For each case the patient's age, sex, clinical symptoms, organ involved and the species of schistosoma indentified histologically were recorded. All the investigations were done on paraffin-embedded tissues. The identification of the schistosoma specie from the H\&E slides was based on external features on the ova: the terminal spin for S. haematobium and the lateral spin for S. mansoni. No serological or molecular markers were used. Data were entered into SPSS software (version 18), and analyzed. The results were presented in frequency tables.

\section{Results}

Clinicopathological characteristics of tissue schistosomiasis

During the period of study, 42,340 surgical specimens were received in the institution, of which $151(0.4 \%)$ were histologically confirmed tissue schistosomiasis. The ages of patients ranged from 7 to 81 years with a mean age of $36.3(S D=16.9)$ years. The modal age group was 20-29 years 41(27.2\%) Table 1. Majority of the patients were males (64.2\%). A total of 129(85.4\%) had complains at the time of presentation, and many of them (35.6\%) presented with haematuria (Table 1). The commonest schistosome identified was S. haematobium (98.7\%) with only $2(1.3 \%)$, S. mansoni (in the spinal cord and the small bowel). The pelvic organs affected were; appendix (41.7\%), urinary bladder $(36.4 \%)$, colon $(4.6 \%)$, cervix $(3.3 \%)$, ureters $(3.3 \%)$ and cervix (2.7\%) Table 1 . Thirty-one (20.5\%) of the cases had associated malignancies.

\section{Male and female tissue schistosomiasis}

The ages of 97(64.2\%) males diagnosed with pelvic tissue schistosomiasis ranged from 7 to 80 years with a mean of 36.4 years ( $S D=16.5$ ) and a modal age group of 30-39 years (28.9\%). The appendix was most commonly affected 48 (49.5\%) (Table 2).

The ages of the (35.8\%) females with tissue schistosomiasis ranged from 7-81 years with a mean of 36.0 years $(S D=17.8)$ and a modal age group of $20-29$ years (37.0\%). In the females schistosoma ova were most commonly found in the bladder (40.7\%) (Table 2).

A total of $17(11.3 \%)$ of schistosomiasis involved the genital tracts: $7(41.2 \%)$ in males and 10(66.7\%) in females (Table 2). The distribution of the male genital tract schistosomiasis

Table 1. Clinicopathological characteristics of tissue schistosomiasis.

\begin{tabular}{lllllllllll}
\hline Age(years) & $\mathbf{0 - 9}$ & $\mathbf{1 0 - 1 9}$ & $\mathbf{2 0 - 2 9}$ & $\mathbf{3 0 - 3 9}$ & $\mathbf{4 0 - 4 9}$ & $\mathbf{5 0 - 5 9}$ & $\geq \mathbf{6 0}$ & & \\
\hline $\mathrm{N}(\%)$ & $2(1.3)$ & $19(12.6)$ & $41(27.2)$ & $35(23.2)$ & $24(15.1)$ & $10(6.6)$ & $20(13.2)$ & & & \\
\hline Symptoms & Haem & RIF mass & Abd pain & Urinary S & Flank pain & Menorr & Scrotal M & Others \\
$\mathrm{N}(\%)$ & $42(31.6)$ & $33(24.8)$ & $32(24.1)$ & $7(5.3)$ & $4(3.0)$ & $4(3.0)$ & $3(2.3)$ & $8(7.0)$ \\
\hline Ova distribution & App & U.bladder & Colon & Ureters & Fallo. T & Cervix & Sperm. C & Prost & Others \\
$\mathrm{N}(\%)$ & & $63(41.7)$ & $55(36.4)$ & $7(4.6)$ & $6(4.0)$ & $5(3.3)$ & $4(2.6)$ & $4(2.6)$ & $3(2.0)$ & $4(2.6)$ \\
\hline
\end{tabular}

KEY: Haem=Haematuria; RIF mass=Right iliac fossa mass; Abd pain=Abdominal pain; Urinary $S=U$ rinary symptoms; Menorr=Menorrhagia; Scrotal M=Scrotal mass; App=Appendix; U.bladder=Urinary bladder; Fallo. T=Fallopian tube; Sperm. $\mathrm{C}=$ Spermatic cord; Prost=Prostate

Table 2. Comparing the clinicopathological characteristics of male and female tissue schistosomiasis.

\begin{tabular}{lllllllllll}
\hline Age(years): & $\mathbf{0 - 9}$ & $\mathbf{1 0 - 1 9}$ & $\mathbf{2 0 - 2 9}$ & $\mathbf{3 0 - 3 9}$ & $\mathbf{4 0 - 4 9}$ & $\mathbf{5 0 - 5 9}$ & $\mathbf{2 6 0}$ & Total \\
\hline Male(N/\%) & $1(1.0)$ & $14(14.4)$ & $21(21.6)$ & $\mathbf{2 8}(\mathbf{2 8 . 8})$ & $16(16.5)$ & $5(5.2)$ & $12(12.4)$ & $97(100.0)$ \\
Female(N/\%) & $1(1.9)$ & $5(9.3)$ & $\mathbf{2 0}(\mathbf{3 7 . 0})$ & $7(13.0)$ & $8(14.8)$ & $5(9.3)$ & $8(14.8)$ & $54(100.0)$ \\
\hline Symptoms & Haem & RIF mass & Abd pain & Urinary S & Flank pain & Menorr & Scrotal M & Others & Total \\
\hline Male(N/\%) & $\mathbf{2 7 ( 3 0 . 0 )}$ & $26(28.9)$ & $22(24.4)$ & $5(5.6)$ & $3(3.3)$ & $0(0.0)$ & $3(3.3)$ & $4(4.4)$ & $90(100.0)$ \\
Female(N/\%) & $\mathbf{1 5}(\mathbf{3 4 . 9})$ & $7(16.3)$ & $9(20.9)$ & $2(4.7)$ & $1(2.3)$ & $4(9.3)$ & $0(0.0)$ & $5(11.6)$ & $43(100.0)$ \\
\hline Ova distribution & App & U.bladder & Colon & Ureters & Genital orgs & Spinal. C & Others & Total \\
\hline Male(N/\%) & $48(49.5)$ & $33(34.1)$ & $2(2.1)$ & $4(4.1)$ & $7(7.2)$ & $1(1.0)$ & $2(2.1)$ & $97(100.0)$ \\
Female(N/\%) & $15(27.8)$ & $22(40.7)$ & $4(7.4)$ & $1(1.9)$ & $10(18.5)$ & $1(1.9)$ & $1(1.9)$ & $54(100.0)$ \\
\hline
\end{tabular}

KEY: Genital orgs=Genital organs; Spinal.C=Spinal cord 
Der et al. Pathology Discovery 2015,

were; prostate $3(42.9 \%)$, scrotum $2(28.6 \%)$ and spermatic cord 2(28.6\%). In females, the fallopian tubes were most commonly affected (50.0\%).

\section{Associations of tissue schistosomiasis with cancer}

There were 31 (20.5\%) cases of cancer associated with tissue schistosomiasis. The ages of these patients ranged from 29-81 years, with a mean age of $52.1(\mathrm{SD}=14.6)$ years and the modal age group was 60 years and above (38.7\%). Most (64.55\%) of the patients were males. Majority of the patients presented with haematuria (83.9\%). The urinary bladder was the organ most commonly affected (93.6\%), and there were one case each of the cervix and prostate (3.2\%). These cancers were Squamous Cell Carcinoma (71.0\%), Transitional Cell Carcinoma (25.85) and one (3.2\%) adenocarcinoma of the prostate (Table 3).

\section{Discussion}

Tissue schistosomiasis is the third most neglected tropical disease in the world, being a major cause of morbidity and mortality in developing countries in Africa, South America, the Caribbean, the Middle East, and Asia, and affecting approximately 250 million people [1-3]. The prevalence of tissue schistosomiasis in this current study was $0.4 \%$. Britta et al., in their study found the prevalence of schistosomiasis to be $0.7 \%$, a value higher than what we found in this current study (0.4\%).

We found $98.7 \%$ of tissue schistosomiasis to be due to $S$. haematobium and only $1.3 \%$ due to S. mansoni. This finding is similar to studies in the endemic regions of the world such as Egypt, where the commonest species is S. haematobium $[5,6]$.

We found that almost all pelvic and perineal organs in both sexes were involved in schistosomiasis. This could possibly be due to the close relationship between the vessels of the pelvis organs and the urinary bladder that enables the parasite to easily change location to virtually any organ in the pelvis.

The common organs involved in this study were; appendix $(41.7 \%)$, urinary bladder (36.4\%), colon $(4.6 \%)$, ureters $(4.0 \%)$, Fallopian tube (3.3\%), cervix (2.65) and prostate (2.0\%). Alam et al., [8] also found the appendix to be the organ that is most commonly affected, similar to our findings. This however differs from the studies by Britta et al., [4] and Gelfand et al., [7] which found the urinary bladder to be the organ most commonly affected.

The mean age of patients with pelvic schistosomiasis in our study was 36.3 years $(S D=16.9)$, with a modal age group of 20-29 years. Some previous clinical studies found the incidence of schistosomiasis to rise with age and peaks usually between ages 15 and 20 years [9-13]. Our peak age group of 20-29 years is relatively similar to these studies. It however differs from other clinical studies conducted along the Volta basin, in Ghana (1970 to 1990), and outside Ghana which found children under the ages of 15 years to be commonly affected [14-16].

Majority (64.2\%) of the patients in this study were males. Infection rates and severity vary with male specific out-door activities such as farming, fishing and swimming which exposes them most likely to infected water [9,17]. Our finding supports studies that found males to be more commonly affected $[9,17]$ but differs from others that found females to be commonly affected [18]. Published data has found the clinical presentation of schistosomiasis to vary greatly in the mode of presentation and severity $[19,20]$. It is found that symptoms depend on the anatomic location of the worm and ova. Ova deposited in the tissue incite a chronic inflammatory response around them leading to fibrosis. In some the fibrosis is marked, whereas in others they appear to provoke little or no tissue reaction. As a general rule the greater the deposition of the ova, the greater the anatomic disturbance of the organs. In such an instance one might expect symptoms [21-23]. Eighty-five percent $(85 \%)$ of the patients in this study had complains at the time of presentation, and these varied depending on the organ involved. The common symptoms were haematuria (35.6\%) and right iliac fossa pain (24.8\%). The varied nature of patient's symptoms in this study is thus in accord with previous studies.

Female genital tract schistosomiasis has been reported in the past, and in some studies the prevalence is as high as

Table 3. Clinico-pathological characteristics pelvic tissue schistosomiasis associated with cancer.

\begin{tabular}{lllllllll}
\hline Age(years) & $\mathbf{0 - 9}$ & $\mathbf{1 0 - 1 9}$ & $\mathbf{2 0 - 2 9}$ & $\mathbf{3 0 - 3 9}$ & $\mathbf{4 0 - 4 9}$ & $\mathbf{5 0 - 5 9}$ & $\mathbf{6 0}$ & Total \\
$\mathrm{N}(\%)$ & $0(0.0)$ & $0(0.0)$ & $1(3.2)$ & $6(19.4)$ & $9(29.7)$ & $3(9.7)$ & $12(38.7)$ & $31(100.0)$ \\
\hline Symptoms & Haem & UB mass & Bleeding PV & Dysuria & Obst uropathy & Total \\
N(\%) & $26(86.7)$ & $2(6.7)$ & $1(3.3)$ & $1(3.3)$ & $1(3.3)$ & $30(100.0)$ \\
\hline Gender & Male 20(64.5) & Female 11(35.3) & & $31(100.0)$ \\
\hline Ova distribution & U.bladder & Cervix & Prost & Total \\
N/\% & 29(93.6) & $1(3.2)$ & $1(3.2)$ & $31(100.0)$ \\
\hline Cancers (Histology) & SCC & TCC & Adenoca & Total \\
N/\% & 22(71.0) & $8(25.8)$ & & $1(3.2)$ & $31(100.0)$ \\
\hline
\end{tabular}

KEY: $\mathrm{PV}=$ Per vaginam; Obst=Obstructive; $\mathrm{SCC}=$ Squamous cell carcinoma; $\mathrm{TCC}=$ Transitional cell carcinoma; Adenoca $=$ Adenocarcinoma 
Der et al. Pathology Discovery 2015,

http://www.hoajonline.com/journals/pdf/2052-7896-3-1.pdf

doi: 10.7243/2052-7896-3-1

35-75\% in some African countries [24-26]. The prevalence of $18.0 \%$ genital tract involvement in this study is much lower compared to these other studies. We found the distribution of female genital tract schistosomiasis to be: fallopian tube (50.0\%) cervix (40.0\%) and vulva (10.0\%). Studies in other parts of Africa such as Tanzania and Zimbabwe found the cervix to be the genital structure that is commonly involved by schistosomiasis [27], a finding that differs from the current study.

Studies in parts of Africa such as Cote d'Ivoire, Gabon and Tanzania, have shown that, the commonest complication as sociated with schistosomiasis of the fallopian tube is ectopic gestation [28-30]. One case (25.0\%) of tubal schistosomiasis was associated with ectopic gestation in this study. Possible explanation for the association between schistosomiasis of the fallopian tube and ectopic gestation is that, deposition of schistosome ova is associated with chronic inflammation and fibrosis and this mechanically impairs the tubal motility or the tubal patency leading to ectopic gestation [31-33].

Forty percent of female genital tract schistosomiasis in this study involved the cervix. This agreed with publications that found the cervix as a common site [34] but differs from others that did not find the cervix as a common site of female genital schistosomiasis $[35,36]$. Schistosomiasis of the female genital tract causes damage to the epithelium especially in the sexually active age group, and could predispose the individual to sexually transmitted infections such as; HIV, HPV infections, Neisseria gonorrhoeae, Chlamydia trachomatis, Mycoplasma genitalium, or Trichomonas vaginalis [37-39]. This seens to suggest that, the females $(40.0 \%)$ with genital tract schistosomiasis in this current study are equally at risk of sexually transmitted infections.

Schistosomiasis of the prostate is rare [40]. In this study it accounted for $42.9 \%$ of all the male genital tract schistosomiasis and $3.1 \%$ of male schistosomiasis in general. Our value of $3.1 \%$ may suggest that prostatic involvement by schistosomiasis is not rare in Ghana and hence the need for further studies. There were two cases each of scrotal $(28.6 \%)$ and spermatic cord (28.6\%) involvement and these may be associated with male infertility due to fibrosis narrowing of the cord lumen.

\section{Association of tissue schistosomiasis with cancers}

Schistosomiasis is known to be associated with malignant disease of the urinary bladder. Ferguson in 1991 raised the hypothesis that a causal relationship exists between schistosomiasis and carcinoma of the bladder [36]. This association was later found to be caused by Schistosoma haematobium infection in geographical locations in which the prevalence of this parasite is high $[41,42]$. About $21.0 \%$ of tissue schistosomiasis in this study were associated with various cancers. Fifty-six percent of the cancers were squamous cell carcinoma, $41.0 \%$ transitional cell carcinoma and $3.0 \%$ adenocarcinoma of the prostate. Patients with cancers associated with tissue schistosomiasis in this study were relatively older, with mean age of $52.7(\mathrm{SD}=14.6)$ years. This differs from some studies in India, China and Egypt that found schistosoma associated cancers in younger ages with mean ages of 46.7 years [43] and 36.9 years $[\mathbf{4 4 , 4 5}$ respectively. Males were more commonly affected and this is similar to studies in Egypt [44,45]. Squamous cell carcinoma was the commonest histological subtype (71.0\%), and and it most commonly involved the bladder (93.6\%). Studies elsewhere in Africa and the Middle East have shown that, chronic infection with Schistosoma hematobium is associated with bladder cancer, majority of which were squamous cell carcinomas $[47,48]$.

The concomitant presence of adenocarcinoma of the prostate and schistosomiasis is very rare. There are few case reports of prostatic schistosomiasis and adenocarcinoma. Cohen et al., [49] reported three cases in South Africa, in all the three cases, prostate cancer was associated with the presence of multiple ova of S. haematobium. Similarly, Albert et al., [50] also reported a case of prostate cancer with schistosomiasis in a [46] year young old patient. In the current study, there were 3 cases of schistosomiasis of prostate, one (33.3\%) of which had associated adenocarcinoma. Our finding may suggest that, the association of prostatic schistosomiasis and adenocarcinoma may not be rare in Ghana.

We found a case of cervical carcinoma associated with schistosomiasis. Some studies have reported this association and our finding, thus supports these studies [51].

\section{Conclusions}

We found a prevalence of $0.4 \%$ tissue schistosomiasis among surgical specimens our study. Young male were more commonly affected. The commonest species identified was S. haematobium and the appendix was the most commonly affected organ. About $20.5 \%$ of the cases were associated with cancer and this was in relatively older age groups. The most common cancer was squamous cell carcinoma of the urinary bladder.

\section{Competing interests}

The authors declare that they have no competing interests.

Authors' contributions

\begin{tabular}{|l|c|c|c|c|}
\hline Authors' contributions & EMD & SEQ & JEM & TY \\
\hline Research concept and design & $\checkmark$ & $\checkmark$ & -- & $\checkmark$ \\
\hline Collection and/or assembly of data & $\checkmark$ & -- & -- & -- \\
\hline Data analysis and interpretation & $\checkmark$ & $\checkmark$ & -- & -- \\
\hline Writing the article & $\checkmark$ & $\checkmark$ & $\checkmark$ & $\checkmark$ \\
\hline Critical revision of the article & -- & -- & -- & -- \\
\hline Final approval of article & $\checkmark$ & $\checkmark$ & $\checkmark$ & $\checkmark$ \\
\hline Statistical analysis & $\checkmark$ & $\checkmark$ & -- & -- \\
\hline
\end{tabular}

\section{Acknowledgement}

Our thanks to pathology colleagues as well as all technical staff of the Department of Pathology, Korle-Bu Teaching Hospital, Accra, Ghana, for their assistance and support. 
Der et al. Pathology Discovery 2015,

\section{Publication history}

Editor: Shahla Masood, University of Florida, USA.

EIC: Markus H. Frank, Harvard Medical School, USA.

Received: 30-Sep-2014 Final Revised: 26-Nov-2014

Accepted: 26-Dec-2014 Published: 02-Jan-2015

\section{References}

1. Scistosomiasis. World Health Organization. 2010.

2. Chitsulo L, Engels D, Montresor A and Savioli L. The global status of schistosomiasis and its control. Acta Trop. 2000; 77:41-51. | Article | PubMed

3. King C.H and Mahmoud A.A.F. Schistosoma and other trematodes. In: Gorbarch S.L., Bartlett J.G., Lacklow N.R. eds. Infectious Diseases. Philadelphia: W.B. Saunders Company, 1998.

4. Swai B, Poggensee G, Mtweve S and Krantz I. Female genital schistosomiasis as an evidence of a neglected cause for reproductive ill-health: a retrospective histopathological study from Tanzania. BMC Infect Dis. 2006; 6:134. | Article | PubMed Abstract | PubMed Full Text

5. Feldmeier H, Poggensee G, Krantz I and Helling-Giese G. Female genital schistosomiasis. New challenges from a gender perspective. Trop Geogr Med. 1995; 47:S2-15. I PubMed

6. Feldmerier H, Daccal RC, Martins MJ, Soares V and Martin R. Genital manifestation of schistosomiasis mansoni: Important but neglected. Mem Inst Oswaldo Cruz. 1998; 93 Suppl:1127-133. | Article

7. Gelfand M. The diagnosis and prognosis of schistosomiasis. Am J Trop Med Hyg. 1949; 29:945-58. I PubMed

8. Alam K, Maheshwari V, Jain A, Siddiqui F, Haq M, Prasad S and Hasan A Schistosomiasis. A case series with review of literature. The Internet Journal of Infectious Diseases. 2008; 7:1.

9. Mwanakasale V, Siziya S, Mwansa J, Koukounari A and Fenwick A. Impact of iron supplementation on schistosomiasis control in Zambian school children in a highly endemic area. Malawi Med J. 2009; 21:12-8. | Article | PubMed Abstract | PubMed Full Text

10. Leder K and Weller P. Epidemiology, pathogenesis, and clinical features of schistosomiasis. UpToDate. 2009; 1-9.

11. Hagan P and Gryseels B. Schistosomiasis research and the European Community. Trop Geogr Med. 1994; 46:259-68. | PubMed

12. King $\mathrm{CH}$, Keating CE, Muruka JF, Ouma JH, Houser $\mathrm{H}$, Siongok TK and Mahmoud AA. Urinary tract morbidity in schistosomiasis haematobia: associations with age and intensity of infection in an endemic area of Coast Province, Kenya. Am J Trop Med Hyg. 1988; 39:361-8. I PubMed

13. Weekly epidemiological record. World health Organization. 2010; 85:157-164.

14. Adiamah JH. Quarterly and Annual Lakeside Health Reports for the Volta River Authority. Akosombo, Ghana: Lakeside Health Unit, VRA:1974-1984.

15. Quarterly and Annual Reports for VRA, Akosombo Hospital. Akosombo, Ghana: Volta River Authority; 1984-1996.

16. Friedman JF, Mital P, Kanzaria HK, Olds GR and Kurtis JD. Schistosomiasis and pregnancy. Trends Parasitol. 2007; 23:159-64. | Article I PubMed

17. Opoku AK. Quarterly and Annual Reports for Volta River Authority. Akosombo, Ghana: Lakeside Health Unit, VRA; 1974-1978.

18. WHO-TDR. World health organization. 2010. | Website

19. Kjetland EF, Leutscher PD and Ndhlovu PD. A review of female genital schistosomiasis. Trends Parasitol. 2012; 28:58-65. | Article I PubMed

20. Poggensee $\mathrm{G}$ and Feldmeier $\mathrm{H}$. Female genital schistosomiasis: facts and hypotheses. Acta Trop. 2001; 79:193-210. | Article | PubMed

21. Nmorsi O, Ukwandu N, Egwungenya O and Obhiemi N. Evaluation of CD4(+)/CD8(+) status and urinary tract infections associated with urinary schistosomiasis among some rural Nigerians. Afr Health Sci. 2005; 5:126-30. | PubMed Abstract | PubMed Full Text

22. Badmos KB, Komolafe $A O$ and Rotimi O. Schistosomiasis presenting as acute appendicitis. East Afr Med J. 2006; 83:528-32. | PubMed
23. Terada T. Schistosomal appendicitis: incidence in Japan and a case report. World J Gastroenterol. 2009; 15:1648-9. I Article I PubMed Abstract I PubMed Full Text

24. Hotez PJ, Fenwick A and Kjetland EF. Africa's 32 cents solution for HIV/ AIDS. PLoS Negl Trop Dis. 2009; 3:e430. | Article | PubMed Abstract | PubMed Full Text

25. Swai B, Poggensee G, Mtweve S and Ingela K. Female genital schistosomiasis as an evidence of a neglected cause for reproductive ill-health: a retrospective histopathological study from Tanzania. BMC Infect. Dis. 2006; 23:134.

26. Gelfand M, Ross MD, Blair DM and Weber MC. Distribution and extent of schistosomiasis in female pelvic organs, with special reference to the genital tract, as determined at autopsy. Am J Trop Med Hyg. 1971; 20:846-9. | PubMed

27. Kjetland EF, Leutscher PD and Ndhlovu PD. A review of female genital schistosomiasis. Trends Parasitol. 2012; 28:58-65. | Article | PubMed

28. Ville $Y$, Leruez M, Picaud A, Walter P and Fernandez H. Tubal schistosomiasis as a cause of ectopic pregnancy in endemic areas?; a report of three cases. Eur J Obstet Gynecol Reprod Biol. 1991; 42:77-9. Article I PubMed

29. Loubière R. La bilharziose en Côte d'Ivoire. Med Afr N. 1977; 24:453.

30. Scheller R. Genitalbilharziose und Extrauteringravidität. Zb/ Gynäkol. 1974; 96:88-92.

31. Feldmeier H, Poggensee G, Krantz I and Helling-Giese G. Female genital schistosomiasis. New challenges from a gender perspective. Trop Geogr Med. 1995; 47:S2-15. I PubMed

32. Berg J. [Bilharziosis of the female sexual organs]. Zentralb/ Gynakol. 1972; 94:673-7. | PubMed

33. Hoffmann $\mathrm{H}$ and Bauerfeind I. High tissue egg burden mechanically impairing the tubal motility in genital schistosomiasis of the female. Acta Obstet Gynecol Scand. 2003; 82:970-1. I Article I PubMed

34. Letterie GS and Sakas L. Proximal tubal obstruction associated with tubal schistosomiasis. Int J Gynaecol Obstet. 1992; 37:293-6. | Article | PubMed

35. Mosunjac MB, Tadros T, Beach R and Majmudar B. Cervical schistosomiasis, human papilloma virus (HPV), and human immunodeficiency virus (HIV): a dangerous coexistence or coincidence? Gynecol Oncol. 2003; 90:211-4. I Article | PubMed

36. Oliveira FA, Soares VL, Dacal AR, Cavalcante FG, Mesquita AM, Fraga $\mathrm{F}$, Lang $\mathrm{K}$ and Feldmeier $\mathrm{H}$. Absence of cervical schistosomiasis among women from two areas of north-eastern Brazil with endemic Schistosoma mansoni. Ann Trop Med Parasitol. 2006; 100:49-54. | Article I PubMed

37. Qunhua L, Jiawen Z, Bozhao L, Zhilan P, Huijie Z, Shaoying W, Delun M and $\mathrm{Hsu} \mathrm{LN}$. Investigation of association between female genital tract diseases and Schistosomiasis japonica infection. Acta Trop. 2000; 77:179-83. | Article | PubMed

38. Kjetland EF, Ndhlovu PD, Gomo E, Mduluza T, Midzi N, Gwanzura L, Mason PR, Sandvik L, Friis H and Gundersen SG. Association between genital schistosomiasis and HIV in rural Zimbabwean women. AIDS. 2006; 20:593-600. | Article | PubMed

39. Downs JA, Mguta C, Kaatano GM, Mitchell KB, Bang H, Simplice H, Kalluvya SE, Changalucha JM, Johnson WD, Jr. and Fitzgerald DW. Urogenital schistosomiasis in women of reproductive age in Tanzania's Lake Victoria region. Am J Trop Med Hyg. 2011; 84:364-9. | Article | PubMed Abstract | PubMed Full Text

40. Leutscher PD, Ramarokoto CE, Hoffmann S, Jensen JS, Ramaniraka V, Randrianasolo B, Raharisolo C, Migliani R and Christensen N. Coexistence of urogenital schistosomiasis and sexually transmitted infection in women and men living in an area where Schistosoma haematobium is endemic. Clin Infect Dis. 2008; 47:775-82. | Article I PubMed

41. Lambertucci JR, Voieta I and Barbosa AJ. Schistosomiasis mansoni of the prostate. Rev Soc Bras Med Trop. 2006; 39:233-4. I Article I PubMed

42. Kjetland EF, Kurewa EN, Ndhlovu PD, Midzi N, Gwanzura L, Mason PR, Gomo E, Sandvik L, Mduluza T, Friis H and Gundersen SG. Female genital schistosomiasis--a differential diagnosis to sexually transmitted disease: 
Der et al. Pathology Discovery 2015,

http://www.hoajonline.com/journals/pdf/2052-7896-3-1.pdf

genital itch and vaginal discharge as indicators of genital Schistosoma haematobium morbidity in a cross-sectional study in endemic rural Zimbabwe. Trop Med Int Health. 2008; 13:1509-17. I Article I PubMed

43. Mosunjac MB, Tadros T, Beach R and Majmudar B. Cervical schistosomiasis, human papilloma virus (HPV), and human immunodeficiency virus (HIV): a dangerous coexistence or coincidence? Gynecol Oncol. 2003; 90:211-4. I Article I PubMed

44. Leutscher PD, Ramarokoto CE, Hoffmann S, Jensen JS, Ramaniraka V, Randrianasolo B, Raharisolo C, Migliani R and Christensen N. Coexistence of urogenital schistosomiasis and sexually transmitted infection in women and men living in an area where Schistosoma haematobium is endemic. Clin Infect Dis. 2008; 47:775-82. | Article | PubMed

45. Lambertucci JR, Voieta I and Barbosa AJ. Schistosomiasis mansoni of the prostate. Rev Soc Bras Med Trop. 2006; 39:233-4. I Article I PubMed

46. Malik MO, Veress B, Daoud EH and El-Hassan AM. Pattern of bladder cancer in the Sudan and its relation to schistosomiasis: a study of $\mathbf{2 5 5}$ vesical carcinomas. J Trop Med Hyg. 1975; 78:219-23. | PubMed

47. El-Bolkainy MN, Mokhtar NM, Ghoneim MA and Hussein MH. The impact of schistosomiasis on the pathology of bladder carcinoma. Cancer. 1981; 48:2643-8. | Article | PubMed

48. Chen MC, Chang PY, Chuang CY, Chen YJ, Wang FP, Tang YC and Chou SC. Colorectal cancer and schistosomiasis. Lancet. 1981; 1:971-3. I Article I PubMed

49. Albert Bacelar, Larissa G.M.C. Castro, Aristides Cheto de Queiroz and Eduardo. CaféAssociation between prostate cancer and schistosomiasis in young patients: a case report and literature review. Braz J Infect Dis. 2007; 11:5. I Article

50. Moubayed P, Ziehe A, Peters J, Mwakyoma H and Schmidt D. Carcinoma of the uterine cervix associated with schistosomiasis and induced by human papillomaviruses. Int J Gynaecol Obstet. 1995; 49:175-9. | Article I PubMed

51. Riffenburgh RH, Olson PE and Johnstone PA. Association of schistosomiasis with cervical cancer: detecting bias in clinical studies. East Afr Med J. 1997; 74:14-6. I Article I PubMed

\section{Citation:}

Der EM, Quayson SE, Mensah JE and Tettey Y. Tissue schistosomiasis in accra ghana: a retrospective histopathologic review at the korle-bu teaching hospital (2004-2011). Pathol Discov. 2015; 3:1. http://dx.doi.org/10.7243/2052-7896-3-1 